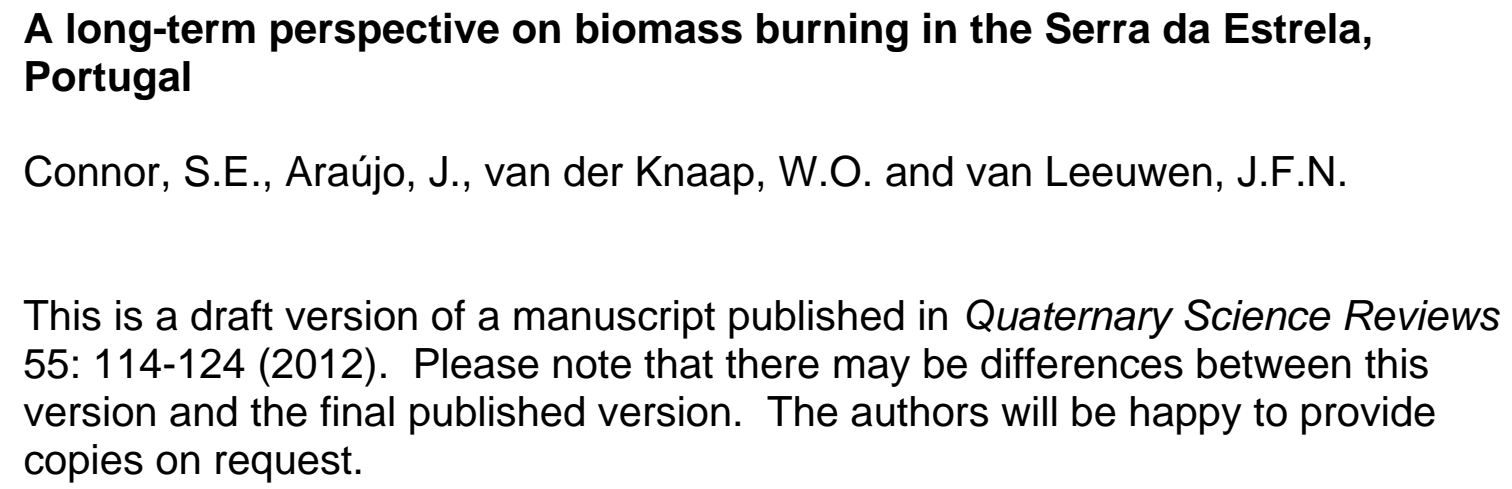




\section{A long-term perspective on biomass burning in the Serra da Estrela, Portugal}

14 Simon E. Connor ${ }^{\mathrm{a} *}$, João Araújo ${ }^{\mathrm{a}}$, Willem O. van der Knaap ${ }^{\mathrm{b}}$, Jacqueline F.N. van 15 Leeuwen $^{\mathrm{b}}$

$16{ }^{a}$ Centre for Marine and Environmental Research, University of the Algarve, Campus de 17 Gambelas, Faro 8005-139, Portugal

$18{ }^{\mathrm{b}}$ Institute of Plant Sciences and Oeschger Centre for Climate Change Research,

19 University of Bern, Altenbergrain 21, Bern 3013, Switzerland

20 *Corresponding author: Tel. +351 289800900; Fax. +351 289800069, E-mail

21 sconnor@ualg.pt

23 Abstract

24 Fire is currently perceived as a major threat to ecosystems and biodiversity in the 25 mountains of the Mediterranean region. Portugal's highest mountain range, the Serra da 26 Estrela, is one of the country's most important protected areas and also the most fireprone. We present a $\sim 14000$-year fire history based on microscopic charred particles in an infilled glacial lake to better understand the antiquity of biomass burning and its effects on Mediterranean vegetation at the Atlantic margin. Results indicate the

30 continuous occurrence of fire in the Serra da Estrela over the period of the record. Two

31 periods of increased fire activity - around 12000-11000 calendar years before the present (cal. a BP) and 3500-2500 cal. a BP - were accompanied by major vegetation changes and followed by long periods of vegetation stabilisation. Cross-correlation

34 analyses reveal that post-fire succession consistently began with herbaceous vegetation, 35 followed by forest and shrubland stages. Past successional trends were often markedly 
36 different to those observed at present. Holocene climatic changes, including shifts in the

37 North Atlantic Oscillation, played a pivotal role in the vegetation development and fire

38 history of the Serra da Estrela. In the late Holocene, human use of fire became a major

39 agent of vegetation change, accelerating the Holocene decline of forests.

\section{$40 \quad$ Keywords}

41 Fire history; Iberian Peninsula; Late Quaternary; Mediterranean; palaeoecology

\section{Introduction}

44 Fire is intrinsically linked to Mediterranean-type ecosystems. Mediterranean plant species present a variety of adaptations to frequent fire, having insulating bark, fireenhanced germination or the ability to resprout after burning (Grove and Rackham, 2001; Allen, 2008). At the same time, uncontrolled fires in Mediterranean vegetation may have catastrophic consequences for human health, economies, natural resources and life itself, constituting major challenges for management authorities in fire-prone regions worldwide (Bowman et al., 2011).

51 Fire is currently a major management issue in Portugal, as the country has the highest

52 density of ignitions in Southern Europe (Moreira et al., 2010). Fires are especially

53 frequent and widespread in the country's protected areas and are therefore considered to 54 pose a major threat to nature conservation and biodiversity (ICN, 2006). The frequency

55 of large fires in these areas appears to have increased during the last few decades, a

56 trend linked, in part, to abandonment of rural land and subsequent accumulation of fuel

57 (Moreira et al., 2010; Jansen, 2011). 
58 Although fire is undoubtedly one of humankind's most ancient tools, our collective fear

59 of wildfires and their capacity for destruction has promoted an attitude of repulsion

60 rather than of understanding. Bowman et al. (2011) argue that we need to know much

61 more about the human dimension of fire regimes, both now and in the past, to reduce

62 the damage caused by fires. The importance of a long-term perspective is particularly

63 great when it comes to fire and the conservation of biodiversity (Tinner and

64 Kaltenrieder, 2005; Colombaroli et al., 2007, 2009; Gil-Romera et al., 2010). High-

65 diversity ecosystems are the product of long periods of evolution and diversification in

66 response to climate, soils, disturbances and plant-animal interactions. The histories of

67 fire and biodiversity in fire-prone ecosystems may be strongly intertwined.

68 Europe's mountains have been identified as environments with an elevated risk of

69 losing biodiversity in the face of predicted climate change (Gitay et al., 2002). This risk

70 could be especially high in the Mediterranean region, which is considered a "hyper-hot"

71 hotspot for plant diversity (Myers et al., 2000; Sanz-Elorza et al., 2003). In this paper, we present a record of microscopic charred particles from lake sediments from the Serra da Estrela mountain range, Portugal. The Serra da Estrela is a Natural Park and is currently the most fire-prone natural area in Portugal (ICN, 2006). Our aims are to: i) determine the antiquity of fires in the ecosystems of the Serra da Estrela, ii) compare the charcoal record to pollen data to gauge fire's effects on the vegetation, and iii) examine how relationships between fire, climate and humans developed through time.

\section{Regional setting}

The Serra da Estrela is an isolated granitic massif of the Central Iberian Cordillera located in the centre-north of Portugal. Its peak, Torre, is the highest point in continental 
Portugal $(1993 \mathrm{~m})$. The range is formed of Hercynian granites which intruded through the surrounding Precambrian-Cambrian schist/greywacke sedimentary complex. Subsequent tectonic movements and erosion have shaped the range, which, broadly speaking, consists of two NE-SW-oriented plateaux, separated by the U-shaped Zêzere Valley and surrounded by deeply incised glacial and fluvial valleys (Fig. 1; ICNB, 2007). Soils on the granitic plateaux are lithosols (rankers), with more developed cambisols occurring over schist bedrock at lower elevations.

The climate of the Serra da Estrela is Mediterranean, transitional between hot-summer and warm-summer types (Csa and Csb in the Köppen classification: AEMet and IM, 2011). The height of the range, combined with its uninterrupted interception of westerly airstreams, lend the Serra da Estrela's climate a distinctly Atlantic character. At Penhas da Saúde (1383 m), annual precipitation averages $2900 \mathrm{~mm}$ (ICNB, 2007). Average annual temperature at the same elevation is $9.2^{\circ} \mathrm{C}$ (AEMet and IM, 2011), dropping to $3-4^{\circ} \mathrm{C}$ at the highest elevations (Mora et al., 2001). Snow cover on the high plateaux may persist for up to 90 days (ICNB, 2007).

The Serra da Estrela, on account of its unique physical and biological characteristics, constitutes a distinct biogeographical area within the Mediterranean region - the Sector Estrelense of Costa et al. (1998). Three bioclimatic belts are distinguished (Pinto da Silva and Teles, 1999; ICNB, 2007): 1) a meso-mediterranean zone below $900 \mathrm{~m}$ elevation, in which remnant forests of oak (Quercus rotundifolia, Q. suber and Q.

102 pyrenaica) and Portuguese laurel (Prunus lusitanica) exist alongside maquis vegetation, agricultural fields, vineyards, olive groves and extensive plantations of Pinus pinaster; a supra-mediterranean belt between 900 and 1600 m, with remnant woods of Quercus pyrenaica, chestnut groves, shrublands and some rye cultivation; and 3) an oromediterranean belt above $1600 \mathrm{~m}$, in which juniper scrub, mat-grass lawns, heaths, 
107 pastures and aquatic communities are found (for further details, see Costa et al., 1998;

108 Pinto da Silva and Teles, 1999). The vascular plant flora of the Serra da Estrela is

109 diverse and includes some 7 endemics, 27 protected species and 92 species of

110 conservation interest; of these, 8 species are considered to be at imminent risk of local

111 extinction (Costa et al., 1998; Pinto da Silva and Teles, 1999; ICNB, 2007).

112 The vegetation history of the Serra da Estrela during the Late-Glacial and Holocene has

113 been relatively well studied through pollen analysis (Romariz, 1950; Janssen and

114 Woldringh, 1981; van den Brink and Janssen, 1985; van der Knaap and van Leeuwen,

115 1995, 1997). The latter authors produced a detailed, 14800-year vegetation history from

116 the Charco da Candieira site, based on analysis of 301 pollen samples and 30

117 radiocarbon dates. Six phases of vegetation development were distinguished:

118 LG: 14800 to 11600 calendar years before the present (cal. a BP) - Alternation

119 between steppic vegetation and open forests in response to Late-Glacial climatic $120 \quad$ oscillations;

121 A: 11600 to 9500 cal. a BP - Development of xerothemic oak-dominated forests 122 under warm, dry climates and in the absence of human influence;

123 B: 9500 to 6400 cal. a BP - Spread of mesothermic forests under a cooler, moister 124 climate, with little human influence;

125 C: 6400 to 3400 cal. a BP - Forest dynamics affected by grazing and deforestation;

126 D: 3400 to 970 cal. a BP - Large-scale deforestation, followed by partial forest

127 recovery;

128 E: 970 to -40 cal. a BP - Complete deforestation of the Serra da Estrela, 129 accompanied by soil erosion, grazing, burning, agriculture and silviculture. 
130 Biomass burning is acknowledged as an important cause of Holocene vegetation

131 changes in the Serra da Estrela, as suggested by the presence of macroscopic charcoal

132 layers in soil profiles (Braun-Blanquet et al., 1952) and sediments from peatbogs around

133 Lagoa Comprida (van den Brink and Janssen, 1985). The latter were dated to

134 approximately 3500 cal. a BP, corresponding to the period of large-scale deforestation

135 (van den Brink and Janssen, 1985). However, the spatial scale of the fires represented

136 by the charcoal layers could be much smaller than the scale of the vegetation changes,

137 as macroscopic charcoal particles are considered to represent local fires (Clark and

138 Royall, 1995).

\section{3. Material and methods}

141 Charco da Candieira (or Lagoa da Candeeira) is an infilled lake situated in a hanging

142 valley on the western side of the Zêzere Valley $\left(40^{\circ} 20^{\prime} 37^{\prime \prime} \mathrm{N}, 7^{\circ} 34^{\prime} 41^{\prime \prime} \mathrm{W}\right)$. At $1400 \mathrm{~m}$

143 elevation, it is the lowest of the glacial lakes of the Serra da Estrela. The site covers

144 approximately 0.8 hectares and its surface dries completely in summer (Costa et al.,

145 2004). The lake basin is considered to have been degraded by rye cultivation and

146 grazing until recently (Costa et al., 2004) and is today surrounded by rocky slopes and

147 scrub vegetation (with a prevalence of Genista, Cytisus, and Erica species, Calluna

148 vulgaris and Juniperus communis). A complete list of plant species in and around the

149 site is given by van der Knaap and van Leeuwen (1995).

150 The samples analysed in the present paper were collected in 1985 and subjected to

151 detailed palynological analysis (van der Knaap and van Leeuwen, 1995, 1997).

152 Subsequently the sample residues (in silicone oil) were archived in glass vials at Utrecht

153 University, the Netherlands. In 2011, we re-mounted the residues of all 293 samples 
154 from the central lake core and counted microscopic charred particles at $400 \times$ magnification on a Leitz Dialux microscope (we were unable to find the 8 'Molinia

156 tussock' samples analysed by van der Knaap and van Leeuwen, 1995). Particles were

157 identified according standard criteria and grouped into two size-classes: 5-50 $\mu \mathrm{m}$ and $158 \quad 50-250 \mu \mathrm{m}$ (see Blackford, 2000).

159 In quantifying microscopic charcoal, Finsinger and Tinner (2005) demonstrated that 160 counting 200 items (charcoal particles and Lycopodium marker spores) is sufficient to 161 obtain a result with a $<5 \%$ error if the ratio between charcoal and marker spores lies

162 between 0.1 and 0.91 . Due to the enormous quantity of charred particles in the

163 Candieira material (ratio between 7 and 1460), we adapted this method by counting the

164 total number of charcoal particles in each field-of-view until a total of at least 200

165 particles was reached; thereafter only fields-of-view and Lycopodium marker spores

166 were counted to reach a minimum of 50 spores. The number of fields-of-view was then

167 used to correct the charcoal counts and calculate charcoal concentrations (particles $\mathrm{cm}^{-}$ $\left.1688^{3}\right)$.

169 Prior to further analysis, a new age-depth model was produced for the Candieira record 170 using a Bayesian approach implemented in OxCal 4.1.7 (Markov chain Monte-Carlo analysis: Bronk Ramsey, 2009) and based on the previously published radiocarbon

172 dates (van der Knaap and van Leeuwen, 1995, 1997). Model acceptability was assessed

173 using $\mathrm{A}_{\text {model }}$ and $\mathrm{A}_{\text {overall }}$ statistics (Bronk Ramsey, 2009).

174 Temporal relationships between charcoal and pollen abundance were analysed using

175 time-series analysis (Green, 1981), implemented in the program PAST 2.11 (Hammer et

176 al., 2001). Pollen proportions, charcoal concentrations and pollen and charcoal

177 accumulation rates were re-sampled at 48-year intervals (median sample resolution), 
178 detrended using a Lowess smoother and the residuals cross-correlated. Sixteen of the

179 most common and indicative pollen taxa were analysed during four periods of relatively

180 constant sediment accumulation: $1500-3500,4500-6500,7500-9500$ and $11500-13500$

181 cal. a BP.

182 Multivariate numerical analysis of the charcoal and pollen data was performed using

183 Principal Components Analysis (PCA) and Detrended Correspondence Analysis (DCA)

184 in the program PC-Ord (McCune and Mefford, 1999). Stratigraphic diagrams were

185 drawn in Tilia 1.7.16 (Grimm, 1992).

\section{4. Results}

188 The age-depth model for the Candieira sequence is shown in Fig. 2. This model has acceptability indices of $63.5 \%\left(\mathrm{~A}_{\text {model }}\right)$ and $63.3 \%\left(\mathrm{~A}_{\text {overall }}\right)$. Estimated errors $(1 \sigma)$ range from 36 to 119 years for individual interpolated samples, with an average of 75 years

191 for the entire sequence. The model is very similar to the previously published models

192 (van der Knaap and van Leeuwen, 1995, 1997) and places the pollen-derived

193 Pleistocene-Holocene boundary (950 cm depth) between 12067 and $11703 \mathrm{cal}$. a BP

$194(2 \sigma)$. Age ranges for each of the pollen zones are given in Fig. 2.

195 Charcoal concentrations are very high throughout the Candieira record (Fig. 3),

196 averaging 11 million particles per $\mathrm{cm}^{3}$ of sediment and reaching peaks of up to 59

197 million. Considering that all of the data included in the global charcoal analysis of

198 Power et al. (2008) had less than 10 million particles per $\mathrm{cm}^{3}$ of sediment, the Candieira

199 values are exceptionally high. The highest total charcoal concentrations and

200 accumulation rates are found in the pollen zone representing large-scale deforestation

201 (D, Fig. 3), while the lowest values are associated with the Late-Glacial (LG, Fig. 3). 
202 Pollen percentages most correlated with total charcoal concentrations over the entire

203 record include Erica arborea ( $r$ : 0.58), E. australis-type (0.56), Poaceae (0.56),

204 Plantago lanceolata-type (0.52) and Genista-type (0.48). Pinus pollen, which is most

205 abundant in Late-Glacial sediments, is negatively correlated with charcoal ( $r$ : -0.53$)$. If

206 the Holocene section of the record is considered alone, the strongest positive correlates

207 with charcoal are taxa representing herbs and shrubs (e.g. Poaceae, Asteraceae, Erica,

208 Genista-type and Plantago lanceolata-type), while the strongest negative correlates are

209 arboreal taxa (e.g. Quercus, Salix, Taxus and Pinus).

210 Candieira's microcharcoal assemblages are clearly dominated by smaller charcoal

211 particles $(5-50 \mu \mathrm{m})$. Larger particles $(50-250 \mu \mathrm{m})$ constitute only a small proportion of

212 the assemblages (average 4\%), but exhibit a slightly different temporal trend to the

213 smaller particles. Peak accumulations of larger charcoal particles, with more than $10^{5}$

214 particles per $\mathrm{cm}^{3}$ per year, occur at approx. $11400,11300,8100,7300,4550,4450$,

2151550,1300 and 1100 cal. a BP.

216 Time-series analysis of pollen and charcoal accumulation rates produced similar results

217 for different taxa, suggesting interdependence between the variables. Fine-scale

218 variations in sedimentation rates could explain this pattern (Colombaroli et al., 2009).

219 Cross-correlations of pollen percentages and charcoal concentrations are less affected

220 by sedimentation rates and a selection of these is shown in Fig. 4.

221 During the earliest period analysed (13500-11500 cal. a BP), Poaceae is positively

222 correlated with charcoal at zero lags, indicative of an immediate response. Grasses are

223 then succeeded by Genista-type, Calluna and Alnus at 1 lag (approx. 50 years after a

224 charcoal peak). Juniperus and Genista-type exhibit positive responses at 5 lags (approx.

225250 years). Pinus responds positively at 11 lags (approx. 550 years). 
226 From 9500-7500 cal. a BP, upland herbs respond positively to charcoal at 1 lag,

227 followed by Alnus at 2-3 lags, with Betula (not shown) at 2 lags. Quercus, which

228 dominates the pollen spectra of this period, responds positively to charcoal at 5-6 lags

229 and Poaceae follows at 7-8 lags, accompanied by Genista-type. Herbs, Erica, Calluna

230 and Alnus respond collectively at 10-12 lags and Quercus exhibits a strong positive

231 response at 14-16 lags.

232 From 6500-4500 cal. a BP, upland herbs exhibit a strong positive response to charcoal

233 at zero lags, mirrored by the strong negative responses of Quercus and Cerealia-type.

234 Erica and Poaceae show significant negative responses at 1 lag, while Pinus and Betula

235 both produce significant positive responses at 1-3 lags. An inversion of this pattern is

236 observed after 6 lags (approx. 300 years), following a positive Genista-type response at

2375 lags. A strong Juniperus response appears at 13 lags.

238 From 3500-1500 cal. a BP, Pinus and Quercus no longer exhibit significant responses

239 to charcoal over the first 10 lags, whereas upland herbs and Cerealia-type show a

240 significant positive response at 1-2 lags. As in the previous period, Erica and Poaceae

241 respond negatively to charcoal at 1 and 2 lags respectively. Alnus has a significant

242 positive response at 3-5 lags, followed by Juniperus and Pteridium at 6 lags (not

243 shown), Calluna and Genista-type at 7-8 lags and Poaceae at 8-9 lags.

244 Both PCA and DCA produced similar results on the first axis, as shown in Fig. 6. DCA

245 axis 1 is influenced by the relationship between negatively correlated taxa such as

246 Erica, Alnus, Ranunculus, Plantago lanceolata-type and Pteridium on the one hand, and

247 positively correlated taxa like Pinus, Artemisia, Calluna, Juniperus and

248 Chenopodiaceae on the other. PCA axis 1 is negatively correlated with Quercus,

249 Pteridium and Taxus, while positive correlates are almost identical to those of the DCA. 


\section{Discussion}

\subsection{Problems of interpretation}

253 Despite the clear evidence for repeated fires in the Candieira record, some important uncertainties must be taken into account. Firstly, the source-area of microscopic charcoal is difficult to define and may amount to hundreds to thousands of metres, depending on particle size, wind velocity and site characteristics (Whitlock and Larsen, 2001). It is difficult to say whether the fires recorded in the Candieira sediments represent local fires in the lake catchment or more regional events. The prevalence of small particles $(<50 \mu \mathrm{m})$ suggests that most of the charcoal derives from regional fires, although over-representation of fine particles can also be caused by catchment processes and sample preparation. Secondly, the transition from lake sediment to wetland

262 sediment at $175-\mathrm{cm}$ depth adds further uncertainty to the source of the charcoal. Lake

263 sediments probably incorporate a greater regional component than wetland sediments 264 due to mixing processes in the water column. Wetland vegetation may directly contribute charcoal to the sediment when the vegetation is burnt and may also trap

266 charred particles amongst its foliage (Tolonen, 1986; Whitlock and Larsen, 2001).

267 Increases in sediment bulk density (Fig. 3) could be an indication of erosion events,

268 which have the potential to introduce secondary charcoal into the sedimentary record.

269 Finally, some fire peaks may have been missed because sediment sampling was not 270 contiguous.

\subsection{Antiquity of biomass burning in the Serra da Estrela}


273 Braun-Blanquet et al. (1952, p. 319) speculated that soil charcoal in the Serra da Estrela

274 represented biomass burning from "hundreds, if not thousands, of years ago". Our data

275 from Charco da Candieira confirm that fires have occurred with regularity since at least

27614,000 cal. a BP. Indeed, even the name 'Candieira' is thought to relate to the deliberate

277 burning of the vegetation by pastoralists, hunters and charcoal producers (Batista,

278 1988).

279 Two major shifts in fire regime can be inferred from the charcoal record; the first at the

280 beginning of the Holocene ( 12000-11000 cal. a BP) and the second in the mid-late

281 Holocene ( 3500-2500 cal. a BP). During each of these periods, charcoal accumulation

282 in Candieira increased quite dramatically, followed by a slight decline and subsequent

283 establishment of a new equilibrium. Both shifts are accompanied by major changes in

284 the palaeovegetation, demonstrating a long-standing link between fire incidence and

285 vegetation change in the Serra da Estrela.

286 Low fire activity around the Serra da Estrela during the steppe vegetation phase of

287 theYounger Dryas is consistent with the interpretation of low fuel availability on the

288 Iberian Peninsula during stadial periods (Daniau et al., 2007). Holocene fire histories

289 from the SW Mediterranean region indicate that fire activity was relatively high during

290 the early Holocene, declined during the mid Holocene and increased again after $\sim 5000$

291 cal. a BP (Carrión, 2002; Tinner et al., 2009; Vannière et al., 2011; Carrión et al., 2012).

292 The Candieira fire history shares aspects of these trends and most closely resembles

293 records from sites in SE Spain and the west coast of Sicily, especially in relation to the

294 major increase in fire activity between $\sim 3500-2500$ cal. a BP (Carrión et al., 2007;

295 Tinner et al., 2009; Gil-Romera et al., 2010). 
296 Unlike most fire histories from the Mediterranean region, the Candieira record gives no

297 indication of millennia-long periods in the mid Holocene when fire activity subsided.

298 Charcoal is constantly present in relatively high concentrations. There are, however,

299 shorter periods from which major charcoal peaks are lacking, i.e. approx. 10500-10000,

$3009000-8500,7000-6500,4500-4000,2500-2000$ cal. a BP. These may simply be

301 sections of the core in which charcoal peaks were missed, although the regular spacing

302 of these intervals could point to an underlying fire cycle. The $4500-4000$ cal. a BP

303 reduction is recorded throughout the Mediterranean region (Vannière et al., 2011).

\section{5.3. Fire's impact on the vegetation}

306 Given the antiquity and recurrence of biomass burning in the Serra da Estrela, it is

307 likely that fire has shaped the vegetation to a substantial degree. As noted above, the

308 two most important vegetation changes - early Holocene afforestation and mid-late

309 Holocene deforestation - are accompanied by major shifts in fire regime and arrival at

310 new metastable states (sensu Oldfield, 1983).

311 On millennial timescales, correlations between charcoal and pollen can reveal the

312 response of vegetation structure to fire activity (e.g. Tinner et al., 2009). Heathland taxa

313 are positively correlated with charcoal in the Candieira record overall, whereas

314 woodland taxa are negatively correlated, suggesting a strong link between Holocene fire

315 activity, forest decline and heathland development in the Serra da Estrela. Similar

316 relationships are observed in other mountain ranges of the Iberian Peninsula (Carrión et

317 al., 2007; Morales-Molino et al., 2011).

318 On shorter timescales of hundreds of years, the interactions between charcoal and pollen

319 abundances may hold a great deal of ecological information on plant species responses 
to fire (Green, 1981; Walker, 1982; Colombaroli et al., 2007, 2009). The Candieira

321 pollen record is sufficiently detailed and well-dated to allow close examination of population dynamics within discrete sections of the Late-Glacial and Holocene.

323 In interpreting the time-series results (Fig. 4), it is important to take into consideration 324 the potential source-area of the charcoal and pollen. Pinus, Olea and Alnus pollen in the

325 Candieira sediments probably derive mostly from lower elevations several kilometres

326 from the site, whereas Quercus, Taxus and Cerealia-type may come from somewhat

327 closer sources, and Erica, Calluna, Genista-type, Pteridium and the dominant upland

328 herbs are thought to come from an area ranging from tens of metres to a few kilometres

329 around the site (van der Knaap and van Leeuwen, 1995). The origin of the charcoal is

330 more difficult to define, though the prevalence of small particles suggests a

331 predominantly regional source.

332 In the four periods studied by time-series analysis, upland herbs appear to be the first

333 taxa to respond positively to a fire event, as indicated by positive correlations between

334 charcoal and pollen abundance at 0 or 1 lag (each lag representing a period of

335 approximately 50 years). The only exception to this is during the Late-Glacial, when the

336 correlation is positive but non-significant. The 'upland herbs' group includes non-

337 wetland taxa and is dominated by Rumex acetosella-type and various Apiaceae,

338 Asteraceae, Fabaceae and Liliaceae, which feature in post-fire vegetation succession in

339 the Serra da Estrela (Jansen, 2011). Poaceae were excluded from the group because

340 grasses occur in the wetland vegetation of Charco da Candieira (van der Knaap and van

341 Leeuwen, 1995).

342 Betula and Alnus, which are both pioneer taxa (van der Knaap and van Leeuwen, 1995),

343 feature prominently in Holocene post-fire successions, usually appearing shortly after 
344 the initial appearance of herbfields. Fire is unlikely to be the main reason for the long-

345 term Betula decline in the Serra da Estrela (cf. van den Brink and Janssen, 1985). Betula

346 is thought to have occurred along mountain streamsides and near the margins of

347 mountain lakes (including Charco da Candieira), while Alnus probably occurred in

348 lower-elevation forests and riparian zones (van der Knaap and van Leeuwen, 1995).

349 In the Holocene periods analysed, Erica often responds negatively to fire over the first 4

350 lags (approx. 200 years). This response is unexpected, as heaths are important in post-

351 fire succession in the Serra da Estrela today (Jansen, 2011). Macrofossil evidence

352 demonstrates that Erica arborea was present near Charco da Candieira from as early as

3538800 cal. a BP, despite low pollen representation at that time (van der Knaap and van

354 Leeuwen, 1995). Pollen filtration (Tauber, 1967) by dense Salix and Betula thickets that

355 developed around the site after fire could explain this phenomenon, as Erica species are

356 insect-pollinated and have poor pollen-dispersal capacity. It is also conceivable that

357 low-statured Erica shrubs were at a competitive disadvantage to taller deciduous species

358 (such as Quercus and Betula) and occupied marginal habitats until complete

359 deforestation took place in the late-Holocene (phase E).

360 Positive Erica and Genista-type responses at longer lag times ( $>6$ lags) in some periods

361 could suggest that these taxa are favoured by repeated burning, considering that major

362 charcoal peaks occur approximately 300 years apart (a similar frequency of microscopic

363 charcoal peaks was observed during the mid-Holocene at $1530 \mathrm{~m}$ elevation in the Sierra

364 de Gádor in Almeria: Carrión et al., 2003, 2012). Alternatively, ecological succession to

365 treeless vegetation may occur after the senescence of oak forests.

366 Oaks (deciduous Quercus) generally respond negatively to fire in the short term, but

367 recover long after fire (approx. 250 years), exhibiting the classic 'climax' response (see 
368 Green, 1981). However, oak behaviour differs from period to period. The significant

369 pre-fire increase at 11500-13500 and 1500-3500 cal. a BP could suggest that fire

370 occurrence was partly related to the accumulation of biomass. In the early-mid

371 Holocene, when Quercus was dominant, initial post-fire recovery is only significant in

372 the earlier phase (B: 7500-9500 cal. a BP) and post-fire decline is only significant in the

373 later period (C: $4500-6500 \mathrm{cal}$. a BP). A second phase of significant oak recovery is

374 observed after a much longer duration - approx. 700 years in phase B and 800 years in

375 phase C. No recovery is observed in phase D. Oak forests clearly had a greater capacity

376 for post-fire regeneration during the early Holocene. Fire and grazing pressure are major

377 factors inhibiting oak forest development in the Serra da Estrela today (Jansen, 2011).

378 Deciduous oaks tend to be more susceptible to post-fire mortality (Catry et al., 2010)

379 and less tolerant of grazing than evergreen oaks (Grove and Rackham, 2001). Under

380 these impacts, the Candieira area's late-successional vegetation may have switched

381 from climax oak forest to plagioclimax broom scrub (Fig. 4).

382 The role of Pinus in the Candieira record is poorly understood because much of its

383 pollen could have arrived from distant pine populations via long-distance pollen

384 transport (van der Knaap and van Leeuwen, 1995). Reduction of oak forest cover would

385 therefore increase the proportion of long-distance Pinus pollen, explaining why negative

386 oak responses to fire are synchronous with positive pine responses (Fig. 4) and vice

387 versa. The only definitive evidence for pine populations around Charco da Candieira

388 comes in the form of macrofossils and stomata of Pinus cf. sylvestris, which reached its

389 upper altitudinal limit in the middle of phase LG but died out completely after the Late-

390 Glacial (van der Knaap and van Leeuwen, 1997). The Pinus sylvestris decline

391 throughout Portugal is attributed to an unfavourable Holocene climate and the influence

392 of fire (Figueiral and Carcaillet, 2005). A few pines (possibly P. pinaster) entered into 
393 forest dynamics in the period $4500-6500$ cal. a BP, constituting an intermediate

394 successional stage between herbfields and scrub vegetation.

395 The post-fire response of grasses shows remarkable consistency through the Holocene.

396 Poaceae macrofossils were found throughout Candieira's Holocene sediments,

397 suggesting that grasses were part of the wetland vegetation (van der Knaap and van

398 Leeuwen, 1995). Grasses may have been shaded out by the post-fire development of

399 deciduous vegetation, as indicated by the similarity between Poaceae and Erica

400 responses to fire through the Holocene (Fig. 4).

401 Cereal pollen, which appears sporadically before 6000 cal. a BP and frequently

402 thereafter, responded to fire in a similar fashion to the other Poaceae in the period 4500-

4036500 cal. a BP, but exhibits a completely different behaviour in the period 1500-3500

404 cal. a BP (Fig. 4). The changing response of cereal pollen to fire in more recent

405 millennia is likely to relate to agricultural practices (see Section 5.4).

406 Post-fire vegetation succession in the present-day broom scrub communities of the Serra

407 da Estrela has been studied by Jansen (2011) using a botanical approach. His model,

408 which includes supra-mediterranean (middle elevation) and oro-mediterranean (higher

409 elevation) variants, is shown in Fig. 5 alongside the successional trends deduced from

410 time-series analysis of the Charco da Candieira pollen and charcoal data. It must be

411 remembered that these data are a palynologically biased picture of the vegetation in

412 which some taxa are over-represented (e.g. Alnus), while others are not represented at

413 all (e.g. Prunus lusitanica). Also, the pollen-to-charcoal comparison represents response

414 to fire, not necessarily the plant community that develops after fire. Nevertheless, there

415 is a striking similarity between the modelled post-fire trajectory for the oro-

416 mediterranean zone and the Late-Glacial pollen response. 
417 The Holocene stages are influenced by the over-representation of wind-pollinated taxa

418 such as Betula and Alnus, as well as the under-representation of insect-pollinated Erica

419 and Genista. Uncertainty concerning the source of Poaceae pollen (wetland vs upland

420 vegetation) in the Candieira record means that Jansen's (2011) initial stage of 'open

421 grasslands' is represented palynologically by upland herbs. Pollen data from the early

422 and late Holocene indicate subsequent succession to a pioneer birch-woodland stage

423 that is not observed in the present day. Betula alba is associated with Quercus

424 pyrenaica forests (Pinto da Silva and Teles, 1999) and may have played a much more

425 important role in the supra-mediterranean zone prior to complete deforestation. The

426 subsequent Alnus stage is also not observed at present and reflects recovery of riparian

427 forest, probably at lower altitudes. In the early Holocene, this stage is followed by oak

428 forests, while in the late Holocene a succession to juniper scrub is observed (similar to

429 Late-Glacial dynamics). In both cases, scrub, grassland or heathland vegetation appears

430 as a final stage, either because of recurrent fire or because of the senescence of oak and

431 juniper communities. The mid-Holocene (4500-6500 cal. a BP) successional trend

432 deduced from pollen is quite different, involving a pine-woods stage not observed at

433 present. Subsequent succession to broom scrub and then heathland is in good agreement

434 with the Jansen (2011) model.

435 These observations indicate that grassland, scrub and heathland communities are

436 important in the long-term vegetation dynamics of the Serra da Estrela and are not

437 simply the product of recent deforestation. Moreover, oak forest requires hundreds of

438 years to recover after fire and it seems that its capacity for recovery has declined

439 through the Holocene. Oak was dominant in the early Holocene when vegetation

440 dynamics were largely governed by successional cycles. Changed climatic conditions

441 and disturbance regimes have favoured the expansion of treeless vegetation. 
442 While the Candieira fire history does not extend into more recent times, vegetation

443 changes during the last thousand years (i.e. further expansion of heathland, felling of

444 oak woods, rye cultivation and establishment of pine, eucalypt and olive plantations; see

445 van der Knaap and van Leeuwen, 1995) have again altered the relationship between fire

446 and vegetation. While the response of individual taxa to fire appears to be quite

447 conservative, as indicated by similar responses in different Holocene periods, the

448 vegetation as a whole may respond to changed disturbance regimes in ways that are

449 difficult to predict.

450 The good news for plant biodiversity is that fire is not a new disturbance in the Serra da

451 Estrela and today's indigenous flora is relatively resilient to burning. Our observations 452 suggest that policies of total fire exclusion (e.g. ICNB, 2009) are unsustainable in the

453 Serra da Estrela and emphasis should instead be placed on reducing the damage caused

454 by large-scale wildfires, which have deleterious effects on habitats and biodiversity

455 (Jansen, 2011). Prescribed fire regimes can play a pivotal role in biodiversity

456 management, but must be supported by ecological knowledge and ecosystem

457 monitoring (Allen, 2008).

\subsection{Interactions between fire, climate and humans}

460 The Holocene fire history of the Mediterranean region is regarded primarily as a

461 reflection of climatic changes (Carrion, 2002; Vannière et al., 2011; Lionello, 2012; cf.

462 Tinner et al., 2009).

463 Interpretation of pollen records from Portugal has given rise to two opposing models for

464 the Holocene palaeoclimate. Based on numerous pollen profiles from lakes along the

465 west coast of Portugal, Queiroz (1999) proposed a wet early Holocene, dry mid 
466 Holocene and hyper-wet late Holocene. Conversely, van der Knaap and van Leeuwen

467 (1995) interpreted the Candieira record as indicating a dry early Holocene and wet mid-

468 Holocene. Interpretation of palaeovegetation in strictly climatic terms is rendered

469 difficult by the influence of sea-level changes ('inundation phases') at the coastal sites

470 (Mateus, 1992; Queiroz, 1999; Queiroz and Mateus, 2004) and prehistoric human

471 impacts on the vegetation throughout the region (Mateus, 1992; van der Knaap and van

472 Leeuwen, 1995; Queiroz, 1999). In addition, Mediterranean climates are characterised

473 by their seasonality, an aspect which has not hitherto emerged from the Portuguese

474 palynological data.

475 Numerical analyses of the Candieira pollen data (Fig. 6) demonstrate that the vegetation

476 history reflects the major climatic fluctuations of the Late-Glacial - including the Older

477 Dryas (Heinrich event 1), Bølling-Allerød interstadial (Greenland interstadial 1) and

478 Younger Dryas - although the radiocarbon age model here appears too young (van der

479 Knaap and van Leeuwen, 1997). Holocene vegetation changes are more difficult to

480 interpret. The PCA result, which closely follows oak pollen percentages, bears some

481 resemblance to the reconstructed winter-temperature curve from Lake Tigalmamine in

482 Morocco (Cheddadi et al., 1998) and possibly reflects the sensitivity of Quercus species

483 to winter temperatures (Colombaroli et al., 2009). The DCA result takes a different

484 course that appears to track the overall trend in increasing warm-season sea-surface

485 temperatures off West Africa (deMenocal et al., 2000). This DCA axis is influenced by

486 the gradual increase in pollen from heathland species, such as Erica and Genista, which

487 have morphological adaptations to temperature variations, desiccating winds and

488 seasonal drought, as well as the ability to resprout after fire (Jansen, 2011). Temperature

489 might be expected to register palaeoecologically in a mountain area such as the Serra da

490 Estrela, although prehistoric human impacts on the vegetation may potentially override 
491 the climatic signal. Gil-Romera et al. (2010) suggest that the early Holocene was

492 characterised by reduced temperature seasonality in SE Iberia, in agreement with the 493 trends reconstructed here.

494 Another climatic signal of interest is the increase in pollen accumulation rates from 495 approximately 13800 to $9700 \mathrm{cal}$. a BP (Fig. 6). High pollen concentrations during this 496 period are also observed in a marine record from the Alboran Sea (Fletcher and Sanchéz 497 Goñi, 2008). These were interpreted as a reflection of increased biomass in response to 498 precession-driven changes in seasonality (Fletcher and Sanchéz Goñi, 2008). The 499 development of the Serra da Estrela's xerothermic forests during the early Holocene 500 may be linked to this precession pattern, which has had a pervasive influence on the 501 Quaternary vegetation history of the Mediterranean region (Tzedakis, 2007; Gil-Romera 502 et al., 2010). Precession, however, has no discernable impact on the fire history from 503 Candieira.

504 Likewise, the Candieira pollen record provides no clear signal of Holocene aridity, 505 possibly because the Serra da Estrela rarely experiences drought in the usual

506 Mediterranean sense of the term. Independent evidence for aridity coincident with 507 increased late-Holocene fire activity in the Serra da Estrela comes from the multi-proxy 508 quantitative palaeoclimatic reconstructions from the Azores (Björck et al., 2006), pollen 509 data from southern Portugal (Fletcher et al., 2007), lowered lake levels in southern 510 Spain and Northern Africa (Lamb and van der Kaars, 1995; Reed et al., 2001; Carrión, 511 2002), as well as widespread sedimentation hiatuses in interdunal lakes in western

512 Portugal (Queiroz and Mateus, 2004). A drier climate may have initiated paludification 513 of Charco da Candieira itself, which switched from a lake to a seasonally dry pond 514 around 3400 cal. a BP (van der Knaap and van Leeuwen, 1995). Arid phases peaking at 515 the beginning of the Holocene (palaeovegetation phase A) and between $\sim 3500-2500$ 
516 cal. a BP (phase D) may have been the trigger for major fires in the region and the

517 subsequent reorganisation of the vegetation of the Serra da Estrela (Fig. 6). Major

518 increases in fire activity are registered across the Mediterranean zone of the Iberian

519 Peninsula between $\sim 3500-2500$ cal. a BP, indicating a coherent regional pattern

520 (Stevenson and Harrison, 1992; Carrión, 2002; Carrión et al., 2007, 2012; Gil-Romera

521 et al., 2010; Vannière et al., 2011; see also Rius et al., 2011).

522 Cyclic aridity phases in SW Europe are thought to be closely linked to variations in the

523 North Atlantic climate system (Reed et al., 2001; Davis and Stevenson, 2007; Fletcher

524 et al., 2007; Vannière et al., 2011), specifically the cooling events identified by Bond et

525 al. (1997). In the Candieira record, major peaks in large charcoal particles at approx.

$52611400-11300,9700,8100,4500,2700$ and 1300 cal. a BP overlap temporally $(2 \sigma)$ with

527 'Bond events' at approx. 11100, 9400, 8100, 4200, 2800 and 1400 cal. a BP,

528 respectively (Fig. 6). The reason that these events registered as local fires, rather than

529 the regional fires indicated by smaller charcoal particles, may be that North Atlantic

530 cooling events had a greater effect on the Serra da Estrela's supra- and oro-

531 mediterranean belts than on the lower elevations due to orographic interception of

532 westerly air-streams.

533 While Holocene climatic changes may have been the driving force behind vegetation

534 change and fire incidence in the Serra da Estrela, human impacts cannot be disregarded,

535 especially in more recent millennia. Van der Knaap and van Leeuwen (1995) used

536 palynological indicators of anthropogenic activity and forest disturbance in the

537 Candieira record to place the earliest signs of human activity in phase B (9500-6400

538 cal. a BP). The first Cerealia-type pollen occurs in the Candieira record at $\sim 10000$ cal. a

$539 \mathrm{BP}$ and it is present almost continuously from 8500 to $7400 \mathrm{cal}$. a BP. Considering that

540 the earliest agricultural settlements in Portugal date to around 7400 cal. a BP (Zilhão, 
541 2001; Zeder, 2008), these occurrences may reflect pollen of steppe grasses (van der

542 Knaap and van Leeuwen, 1995). Other traditional anthropogenic indicators, such as

543 Rumex acetosella-type and Plantago lanceolata-type (Behre, 1981), are not particularly

544 helpful in the Candieira record as they occur throughout the Late-Glacial and Holocene.

545 Sheep and goat herding is the traditional mainstay of the Serra da Estrela's economy.

546 Grazing's direct impact on the Serra da Estrela's vegetation and fire history is unknown;

547 along with fires lit by herders to promote pasture, it is probably quite significant (Braun-

548 Blanquet et al., 1952; van der Knaap and van Leeuwen, 1995). The regular occurrence

549 of spores from dung-inhabiting fungi (e.g. Sporormiella and Podospora: van Geel and

550 Aptroot, 2006) in the Candieira material demonstrates that grazing by wild or domestic

551 animals has a long history in the Serra da Estrela, extending back to the Late-Glacial.

552 The earliest archaeological site in the Serra da Estrela, Buraco da Moura de São Romão,

553 is located $\sim 9 \mathrm{~km}$ WNW of Charco da Candieira on the western flank of the mountains

554 and contains Neolithic, Chalcolithic, Bronze Age and Medieval levels (Senna-Martinez,

555 1993). Analysis of Bronze-Age faunal remains from the $2^{\text {nd }}$ millennium BC provides

556 convincing evidence that pastoral activities, especially sheep and cattle herding, were

557 practised at this time (Cardoso et al., 1998), coincident with widespread deforestation in

558 the Serra da Estrela (van den Brink and Janssen, 1985; van der Knaap and van

559 Leeuwen, 1995). Regional aridity between $\sim 3500-2500$ cal. a BP may have intensified

560 occupation of better-watered mountain areas, leading to the clearance of forests for

561 pasture, or a population increase led to the same outcome.

562 Establishment of Roman roads and settlements in the Serra da Estrela is marked

563 palaeoecologically by the first appearance of Castanea pollen in the Candieira record

564 around 2000 cal. a BP. Roman-era activity was concentrated at the foot of the 
565 mountains, far from the central plateaux (Alarcão, 1993), and no drastic changes are

566 evident in the pollen record from Charco da Candieira.

567 The same cannot be said of the Medieval, a period of rapid population growth that led to

568 the expansion of heathland and virtual disappearance of forests. Historical sources attest

569 to the importance of sheep grazing and rye cultivation at higher elevations (Batista,

570 1988), including in the surroundings of Charco da Candieira (Costa et al., 2004). Cereal

571 cultivation was often practised on common land during the Medieval, alongside animal

572 husbandry, charcoal production, firewood collection, timber harvesting and hunting;

573 deliberate agro-pastoral fires (queimadas, in Portuguese) were associated with many of 574 these activities (Batista, 1988).

575 Substantial amounts $(>15 \%)$ of Cerealia-type pollen in the more recent Candieira

576 sediments are a clear testament to this local activity (Fig. 6). Fire and cereals are

577 strongly related in the period 1500-3500 cal. a BP, with a significant expansion of

578 cereal pollen 50-100 years after fire. This distinctive response is most likely to be a

579 reflection of prehistoric queimadas, possibly in the direct surroundings of Charco da

580 Candieira. Recent increases in pine and olive pollen, on the other hand, come from the

581 establishment of extensive plantations in the valleys and lowlands (van der Knaap and

582 van Leeuwen, 1995).

583 In summary, long-term trends in the fire history from Charco da Candieira can be

584 explained largely by Late-Glacial and Holocene climatic changes, particularly cycles of

585 aridity associated with shifts in the North Atlantic Oscillation. Fire was ever-present in

586 the Serra da Estrela, but, in the hands of prehistoric and historic human populations, it

587 became a major agent of vegetation change, accelerating the Holocene decline of

588 forests. 


\section{Conclusions}

590 Ever since the ice cap and glaciers retreated, fire has always been an important

591 component of the ecosystems of the Serra da Estrela. Fire has directly shaped the

592 composition of the mountain's plant communities. Current trends toward increasing fire

593 incidence in the Serra da Estrela present immediate management difficulties, but are

594 nothing new when viewed from a long-term perspective. The Serra da Estrela has

595 witnessed several periods in the past in which fire incidence appears to have increased

596 dramatically due to climatic factors. In each case, the period of increasing fire activity

597 was followed by a much longer period of stabilisation. Although fire itself does not

598 seem to pose a threat to the region's plant biodiversity, the variety of vegetation

599 responses to fire in the past suggests that changes in climate, land-use and disturbance

600 regimes could have unpredictable outcomes in the future. For this reason it is important

601 to develop a better understanding of fire in the mountains of the Iberian Peninsula, both 602 now and in the historical past.

\section{Acknowledgements}

605 Special thanks to Prof. C. Roel Janssen (Utrecht) for dusting off the Charco da

606 Candieira samples for re-analysis. Thanks also to Florencia Oberli (Bern), Petr Kuneš

607 (Prague), João País (Lisbon) and Tomasz Boski (Algarve) for their assistance and

608 comments. This paper is a contribution to Project SWIRL (PTDC/AAC-

609 CLI/108518/2008), funded by the Portuguese Science Foundation (FCT).

\section{References}


611 Agencia Estatal de Meteorología (AEMet), Insitituto de Meteorologia (IM), 2011.

612 Iberian Climate Atlas: air temperature and precipitation (1971-2000). Ministerio de Medio Ambiente y Medio Rural y Marino.

614 Alarcão, J., 1993. Arqueologia da Serra da Estrela. Instituto da Conservação da Natureza, Parque Natural da Serra da Estrela, Manteigas.

616 Allen, H.D., 2008. Fire: plant functional types and patch mosaic burning in fire-prone ecosystems. Progress in Physical Geography 32: 421-437.

618 Batista, J.D.L., 1988. O povoamento da Serra da Estrela de 1055 a 1223 e outros

619 estudos. Instituto de Cultura e Língua Portuguesa \& Parque Natural da Serra da Estrela, Lisboa/Manteigas.

Behre, K.-E., 1981. The interpretation of anthropogenic indicators in pollen diagrams. Pollen et Spores 23: 225-245.

Berger, A.L., 1978. Long-term variations of caloric insolation resulting from the Earth's orbital elements. Quaternary Research 9: 139-167.

Björck, S., Rittenour, T., Rosén, P., França, Z., Möller, P., Snowball, I., Wastegard, S., Bennike, O., Kromer, B., 2006. A Holocene lacustrine record in the central North Atlantic: proxies for volcanic activity, short-term NAO mode variability, and long-term precipitation changes. Quaternary Science Reviews 25: 9-32.

Blackford, J.J., 2000. Charcoal fragments in surface samples following a fire and the 630 implications for interpretation of subfossil charcoal data. Palaeogeography, Palaeoclimatology, Palaeoecology 164: 33-42. 
632 Bond, G., Showers, W., Cheseby, M., Lotti, R., Almasi, P., deMenocal, P., Priore, P.,

633

634

635

636

637

638

639

640

641

642

643

644

645

646

647

648

649

650

651

652

653

654 Cullen, H., Hajdas, I., Bonani, G., 1997. A pervasive millennial-scale cycle in North Atlantic Holocene and Glacial climates. Science 278: 1257-1266.

Bowman, D.M.J.S., Balch, J., Artaxo, P., Bond, W.J., Cochrane, M.A., D'Antonio, C.M., DeFries, R., Johnston, F.H., Keeley, J.A., Krawchuk, M.A., Kull, C.A., Mack, M., Moritz, M.A., Pyne, S., Roos, C.I., Scott, A.C., Sodhi, N.S., Swetnam, T.W., 2011. The human dimension of fire regimes on Earth. Journal of Biogeography 38: 2223-2236.

Braun-Blanquet, J., Pinto da Silva, A.R., Rozeira, A., Fontes, F., 1952. Resultats de deux excursions géobotaniques a travers le Portugal septentrional et moyen: 1 une incursion dans la Serra da Estrela. Agronomia Lusitana 14: 303-323.

Bronk Ramsey, C., 2009. Bayesian analysis of radiocarbon dates. Radiocarbon 51: 337360.

Carcaillet, C., Almquist, H., Asnong, H., Bradshaw, R.H.W., Carrión, J.S., Gaillard, M.J., Gajewski, K., Haas, J.N., Haberle, S.G., Hadorn, P., Müller, S.D., Richard, P.J.H., Richoz, I., Rösch, M., Sánchez Goñi, M.F., von Stedingk, H., Stevenson, A.C., Talon, B., Tardy, C., Tinner, W., Tryterud, E., Wick, L., Willis, K.J., 2002. Holocene biomass burning and global dynamics of the carbon cycle. Chemosphere 49: 845-863.

Cardoso, J.L., Senna-Martinez, J.C., Valera, A.C., 1998. Aspectos da economia alimentar do Bronze Pleno da Beira Alta: a fauna de grandes mamíferos das «Salas 2 e 20» do Buraco da Moura de S. Romão (Seia). Trabalhos de Arqueologia da EAM 3: 253-261. 
655 Carrión, J.S., 2002. Patterns and processes of Late Quaternary environmental change in a montane region of southwestern Europe. Quaternary Science Reviews 21: 2047-2066.

Carrión, J.S., Fernández, S., González-Sampériz, P., López-Merino, L., Peña, L., Burjachs, F., López-Sáez, J.A., García-Antón, M., Carrión Marco, Y., Uzquiano, P., Postigo, J.M., Barrón, E., Allué, E., Badal, E., Dupré, M., Fierro, E., Munuera, M., Rubiales, J.M., García Amorena, I., Jiménez Moreno, G., Gil Romera, G., Leroy, S., García-Martínez, M.S., Montoya, E., Fletcher, W., Y11, E., Vieira, M., Rodríguez-Ariza, M.O., Anderson, S., Peñalba, C., Gil García, M.J., Pérez Sanz, A., Albert, R.M., Díez, M.J., Morales-Molino, C., Gómez Manzaneque, F., Parra, I., Ruiz Zapata, B., Riera, S., Zapata, L., Ejarque, A., Vegas, T., Rull, V., Scott, L., Abel Schaad, D., Andrade, A., Manzano, S., Navarro, C., Pérez Díaz, S., Moreno, E., Hernández-Mateo, L., Sánchez Baena, J.J., Riquelme, J.A., Iglesias, R., Franco, F., Chaín, C., Figueiral, I., Grau, E., Matos, M., Jiménez Espejo, F., Valle-Hernández, M., Rivas-Carballo, R., Arribas, A., Garrido, G., Muñiz, F., Finlayson, G., Finlayson, C., Ruiz, M.,

674 Carrión, J.S., Fuentes, N., González-Sampériz, P., Sánchez Quirante, L., Finlayson, Pérez Jordá, G., Miras, Y., 2012. Paleoflora y Paleovegetación de la Península J.C., Fernández, S., Andrade, A., 2007. Holocene environmental change in a montane region of southern Europe with a long history of human settlement. Quaternary Science Reviews 26: 1455-1475. 
678 Carrión, J.S., Sánchez-Gómes, P., Mota, J.F., Y11, R., Chaín, C., 2003. Holocene vegetation dynamics, fire and grazing in the Sierra de Gádor, southern Spain.

680 The Holocene 13: 839-849.

681

682

683

684

685

686

687

688

689

690

691

692

693

694

695

696

697

698

699
Catry, F.X., Rego, F., Moreira, F., Fernandes, P.M., Pausas, J.G., 2010. Post-fire tree mortality in mixed forests of central Portugal. Forest Ecology and Management 260: 1184-1192.

Cheddadi, R., Lamb, H.F., Guiot, J., van der Kaars, S., 1998. Holocene climatic change in Morocco: a quantitative reconstruction from pollen data. Climate Dynamics 14: $883-890$.

Clark, J.S., Royall, P.D., 1995. Particle-size evidence for source areas of charcoal accumulation in late Holocene sediments of eastern North American lakes. Quaternary Research 43: 80-89.

Colombaroli, D., Marchetto, A., Tinner, W., 2007. Long-term interactions between Mediterranean climate, vegetation and fire regime at Lago di Massaciuccoli (Tuscany, Italy). Journal of Ecology 95: 755-770.

Colombaroli, D., Tinner, W., van Leeuwen, J., Noti, R., Vescovi, E., Vannière, B., Magny, M., Schmidt, R., Bugmann, H., 2009. Response of broadleaved evergreen Mediterranean forest vegetation to fire disturbance during the Holocene: insights from the peri-Adriatic region. Journal of Biogeography 36: 314-326.

Costa, J.C., Aguiar, C., Capelo, J.H., Lousã, M., Neto, C., 1998. Biogeografia de Portugal Continental. Quercetea 0: 5-56. 
700 Costa, L.T., Fidalgo, J.P., Neves, R., Rufino, R., 2004. Lagoas do Planalto Superior da

701

702

703

704

705

706

707

708

709

710

711

712

713

714

715

716

717

718

719

720 Serra da Estrela. Instituto da Conservação da Natureza, Centro de Zonas Húmidas.

Daniau, A.-L., Sánchez-Goñi, M.F., Beaufort, L., Laggoun-Défarge, F., Loutre, M.-F., Duprat, J., 2007. Dansgaard-Oeschger climatic variability revealed by fire emissions in southwestern Iberia. Quaternary Science Reviews 26: 1369-1383.

Davis, B.A.S., Stevenson, A.C., 2007. The 8.2 ka event and early-mid Holocene forests, fires and flooding in the Central Ebro Desert, NE Spain. Quaternary Science Reviews 26: 1695-1712.

deMenocal, P.B., Ortiz, J., Guilderson, T., Sarnthein, M., 2000. Coherent high- and low-latitude climate variability during the Holocene Warm Period. Science 288 (5474): 2198-2202.

Figueiral, I., Carcaillet, C., 2005. A review of Late Pleistocene and Holocene biogeography of highland Mediterranean pines (Pinus type sylvestris) in Portugal, based on wood charcoal. Quaternary Science Reviews 24: 2466-2476.

Finsinger, W., Tinner, W., 2005. Minimum count sums for charcoal concentration estimates in pollen slides: accuracy and potential errors. The Holocene 15: 293297.

Fletcher, W.J., Boski, T., Moura, D., 2007. Palynological evidence for environmental and climatic change in the lower Guadiana valley, Portugal, during the last 13000 years. The Holocene 17: 481-494. 
Fletcher, W.J., Sánchez Goñi, M.F., 2008. Orbital- and sub-orbital-scale climate impacts on vegetation of the western Mediterranean basin over the last 48,000 yr. Quaternary Research 70: 451-464.

Gil-Romera, G., Carrión, J.S., Pausas, J.G., Sevilla-Callejo, M., Lamb, H.F., Fernández, S., Burjachs, F., 2010. Holocene fire activity and vegetation response in SouthEastern Iberia. Quaternary Science Reviews 29: 1082-1092.

Gitay, H., Suárez, A., Watson, R.T., Dokken, D.J. (Eds.), 2002. Climate Change and Biodiversity: IPCC Technical Paper V. Intergovernmental Panel on Climate Change, Geneva.

Green, D.G., 1981. Time series in postglacial forest ecology. Quaternary Research 15: $265-277$.

Grimm, E.C., 1992. Tilia and Tilia-graph: pollen spreadsheet and graphics programs. Program and Abstracts, 8th International Palynological Congress, September 612, Aix-en-Provence, p. 56.

Grove, A.T., Rackham, O., 2001. The Nature of Mediterranean Europe: an Ecological History. Yale University Press, New Haven.

Hammer, Ø., Harper, D.A.T., Ryan, P.D., 2001. PAST: Paleontological Statistics software package for education and data analysis. Palaeontologia Electronica 4: $1-9$.

Instituto da Conservação da Natureza (ICN), 2006. Relatório sobre incêndios rurais na Rede Nacional de Áreas Protegidas e na Rede Natura 2000. Ministério do Ambiente, do Ordenamento do Território e do Desenvolvimento Regional, Lisboa. 
744 Instituto da Conservação da Natureza e da Biodiversidade (ICNB), 2007. Plano de Ordenamento do Parque Natural da Serra da Estrela: II, Caracterização dos Valores Naturais. Ministério do Ambiente, do Ordenamento do Território e do Desenvolvimento Regional, Lisboa.

Instituto da Conservação da Natureza e Biodiversidade (ICNB), 2009. Plano Prévio de Intervenção em Incêndios Rurais 2009, Parque Natural da Serra da Estrela. Ministério do Ambiente, do Ordenamento do Território e do Desenvolvimento Regional, Lisboa.

Jansen, J., 2011. Managing Natura 2000 in a changing world: the case of the Serra da Estrela (Portugal). PhD thesis, Radboud University.

Janssen, C.R., Woldringh, R.E., 1981. A preliminary radiocarbon dated pollen sequence from the Serra da Estrela, Portugal. Finisterra 16: 299-309.

Lamb, H.F., van der Kaars, S., 1995. Vegetational response to Holocene climatic change: pollen and palaeolimnological data from the Middle Atlas, Morocco. The Holocene 5: 400-408.

Lionello, P. (Ed.), 2012. The Climate of the Mediterranean Region: from the Past to the Future. Elsevier, London.

761 Maher, L., 1972. Nomograms for computing 0.95 confidence limits of pollen data. Review of Palaeobotany and Palynology 13: 85-93. Southwest Portugal. PhD thesis, Utrecht University. 
McCune, B., Mefford, M.J., 1999. PC-ORD: Multivariate Analysis of Ecological Data. MjM Software Design, Gleneden Beach, Oregon.

Mora, C., Vieira, G.T., Alcoforado, M.J., 2001. Daily minimum air temperatures in the Serra da Estrela, Portugal. Finisterra 36(71): 49-60.

Morales-Molino, C., García Antón, M., Morla, C., 2011. Late Holocene vegetation dynamics on an Atlantic-Mediterranean mountain in NW Iberia. Palaeogeography, Palaeoclimatology, Palaeoecology 302: 323-337.

Moreira, F., Catry, F.X., Rego, F., Bacao, F., 2010. Size-dependent pattern of wildfire ignitions in Portugal: when do ignitions turn into big fires? Landscape Ecology 25: 1405-1417.

Myers, N., Mittermeier, R.A., Mittermeier, C.G., da Fonseca, G.A.B., and Kent, J., 2000. Biodiversity hotspots for conservation priorities. Nature 403: 853-858.

Oldfield, F., 1983. Man's impact on the environment: some recent perspectives. Geography 68: 245-256.

Pinto da Silva, A.R., Teles, A.N., 1999. A flora e a vegetação da Serra da Estrela. Parque Natural da Serra da Estrela, Manteigas.

Queiroz, P.F., 1999. Ecologia Histórica da Paisagem do Noroeste Alentejano. Unpublished $\mathrm{PhD}$ thesis, Universidade de Lisboa. Tardiglaciário aos tempos de hoje. In: Tavares, A.A., Tavares, M.J.F., Cardoso, J.L. (Eds.) Evolução Geohistórica do Litoral Português e Fenómenos 

Correlativos: Actas Geologia, História, Arqueologia e Climatologia. Universidade Aberta.

Quézel, P., Médail, F., 2003. Écologie et biogéographie des forêts du bassin méditerranéen. Elsevier, Paris.

Reed, J., Stevenson, A.C., Juggins, S., 2001. A multi-proxy record of Holocene climatic change in southwestern Spain: the Laguna de Medina, Cádiz. The Holocene 11: $707-719$.

Rius, D., Vannière, B., Galop, D., Richard, H., 2011. Holocene fire regime changes from multiple-site sedimentary charcoal analyses in the Lourdes basin (Pyrenees, France). Quaternary Science Reviews 30: 1696-1709.

Romariz, C., 1950. Contribuição da análise polínica no estudo da vegetação primitive da Serra da Estrela. Compte rendu Congrès International Géographie Lisbonne 2: 824-830.

Sanz-Elorza, M., Dana, E.D., González, A., Sobrino, E., 2003. Changes in the highmountain vegetation of the Central Iberian Peninsula as a probable sign of global warming. Annals of Botany 92: 273-280.

Senna-Martinez, J.C., 1993. A ocupação do Bronze Pleno da 'Sala 20' do Buraco da Moura de São Romão. Trabalhos de Arqueologia da EAM 1: 55-76.

Stevenson, A.C., Harrison, R.J., 1992. Ancient forests in Spain: a model for land-use and dry forest management in south-west Spain from 4000 BC to 1900 AD. Proceedings of the Prehistoric Society 58: 227-247. 
807 Tauber, H., 1967. Investigations of the mode of pollen transfer in forested areas. Review of Palaeobotany and Palynology 3: 277-286.

809 Tinner, W., Kaltenrieder, P., 2005. Rapid responses of high-mountain vegetation to 810 early Holocene environmental changes in the Swiss Alps. Journal of Ecology 93: 936-947.

812 Tinner, W., van Leeuwen, J.F.N., Colombaroli, D., Vescovi, E., van der Knaap, W.O., Henne, P.D., Pasta, S., D'Angelo, S., and La Mantia, T., 2009. Holocene environmental and climatic changes at Gorgo Basso, a coastal lake in southern Sicily, Italy. Quaternary Science Reviews 28: 1498-1510.

816 Tolonen, K., 1986. Charred particle analysis. In: Berglund, B.E. (Ed.) Handbook of Holocene Palaeoecology and Palaeohydrology. John Wiley \& Sons, Chichester.

818 Tzedakis, P.C. 2007. Seven ambiguities in the Mediterranean palaeoenvironmental narrative. Quaternary Science Reviews 26: 2042-2066.

820 Van den Brink, L.M., Janssen, C.R., 1985. The effect of human activities during cultural phases on the development of montane vegetation in the Serra da Estrela, Portugal. Review of Palaeobotany and Palynology 44: 193-215.

Van der Knaap, W.O., van Leeuwen, J.F.N., 1995. Holocene vegetation succession and 824 degradation as responses to climatic change and human activity in the Serra da Estrela, Portugal. Review of Palaeobotany and Palynology 89: 153-211.

826 Van der Knaap, W.O., van Leeuwen, J.F.N., 1997. Late Glacial and early Holocene vegetation succession, altitudinal vegetation zonation, and climatic change in the Serra da Estrela, Portugal. Review of Palaeobotany and Palynology 97: 239_ 285. 
830 Van Geel, B., Aptroot, A., 2006. Fossil ascomycetes in Quaternary deposits. Nova Hedwigia 82: 313-329.

832 Vannière, B., Power, M.J., Roberts, N., Tinner, W., Carrión, J., Magny, M., Bartlein, P., 833 Colombaroli, D., Daniau, A.L., Finsinger, W., Gil-Romera, G., Kaltenrieder, P., 834 Pini, P., Sadori, L., Turner, R., Valsecchi, V., Vescovi, E., 2011. Circum835 Mediterranean fire activity and climate changes during the mid-Holocene 836 environmental transition (8500-2500 cal. a BP). The Holocene 21: 53-73.

837 Walker, D., 1982. Vegetation's fourth dimension. New Phytologist 90: 419-429.

838 Whitlock, C., Larsen, C., 2001. Charcoal as a fire proxy. In: J.P. Smol, H.J.B. Birks, 839 W.M. Last (Eds.) Tracking Environmental Changes using Lake Sediments Volume 3: Terrestrial, Algal, and Siliceous Indicators. Kluwer Academic Publishers, Netherlands, pp. 1-23.

842 Zeder, M., 2008. Domestication and early agriculture in the Mediterranean Basin: 843 origins, diffusion, and impact. PNAS 105: 11597-11604.

844 Zilhão, J., 2001. Radiocarbon evidence for maritime pioneer colonization at the origins 845 of farming in west Mediterranean Europe. PNAS 98: 14180-14185. 


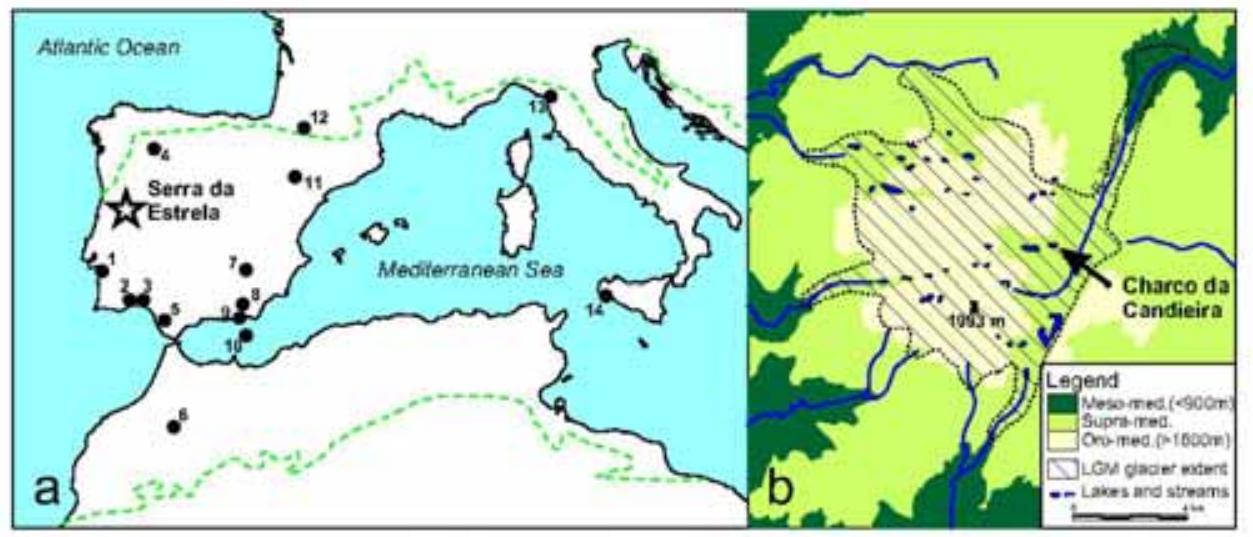

848

849

850

851

852

853

854

855

856

857

858

859

860

861 Estrela (see Section 2), the extent of the most recent glaciation and the distribution of

862 glacial lakes (after Daveau, 1971).

Figure 1. Location of the Serra da Estrela, Portugal (a) and the study site, Charco da

Candieira (b). The dashed line in Fig. 1a indicates the bioclimatic limit of the

Mediterranean region (after Quézel and Médail, 2003). Other sites mentioned in the text are shown: 1. NW Alentejo (Mateus, 1992; Queiroz, 1999; Queiroz and Mateus, 2004);

2. Guadiana Estuary (Fletcher et al., 2007); 3. Laguna de las Madres (Stevenson and Harrison, 1992); 4. Vallefondo (Morales-Molino et al., 2011); 5. Laguna de Medina (Reed et al., 2001); 6. Lake Tigalmamine (Cheddadi et al., 1998; Lamb and van der Kaars, 1995); 7. Lake Siles (Carrión, 2002; Gil-Romera et al., 2010); 8. Baza (Carrión et al., 2007); 9. Gádor (Carrión et al., 2003); 10. Alboran Sea (Fletcher and Sánchez Goñi, 2008); 11. Central Ebro Desert (Davis and Stevenson, 2007); 12. Lourdes Basin (Rius et al., 2011); 13. Lago di Massaciuccoli (Colombaroli et al., 2007); 14. Gorgo Basso (Tinner et al., 2009). Fig. 1b shows the main bioclimatic zones of the Serra da 


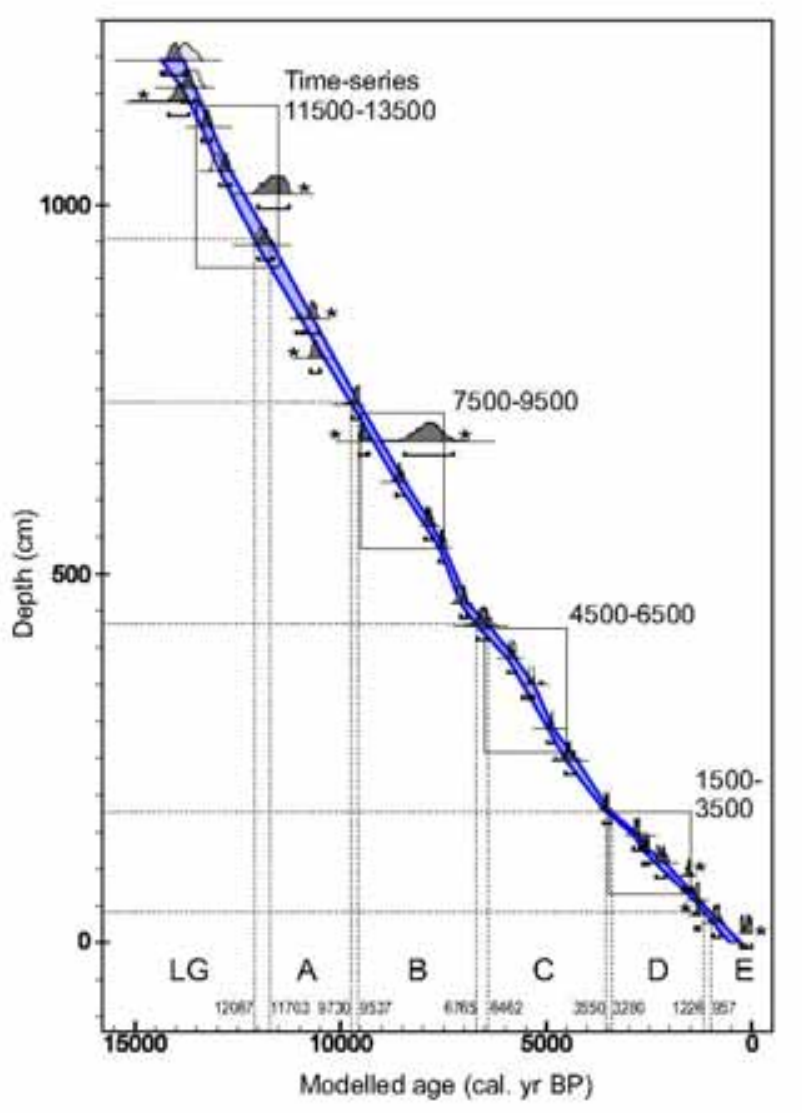

864

865 Figure 2. Age-depth model for the Charco da Candieira sediment record showing

866 probability distributions for each dated level, dates excluded from the model (*) and age

867 ranges for each of the palaeovegetation phases (Section 2). Boxed periods were

868 subjected to time-series analysis (Section 5.3; Fig. 4). 


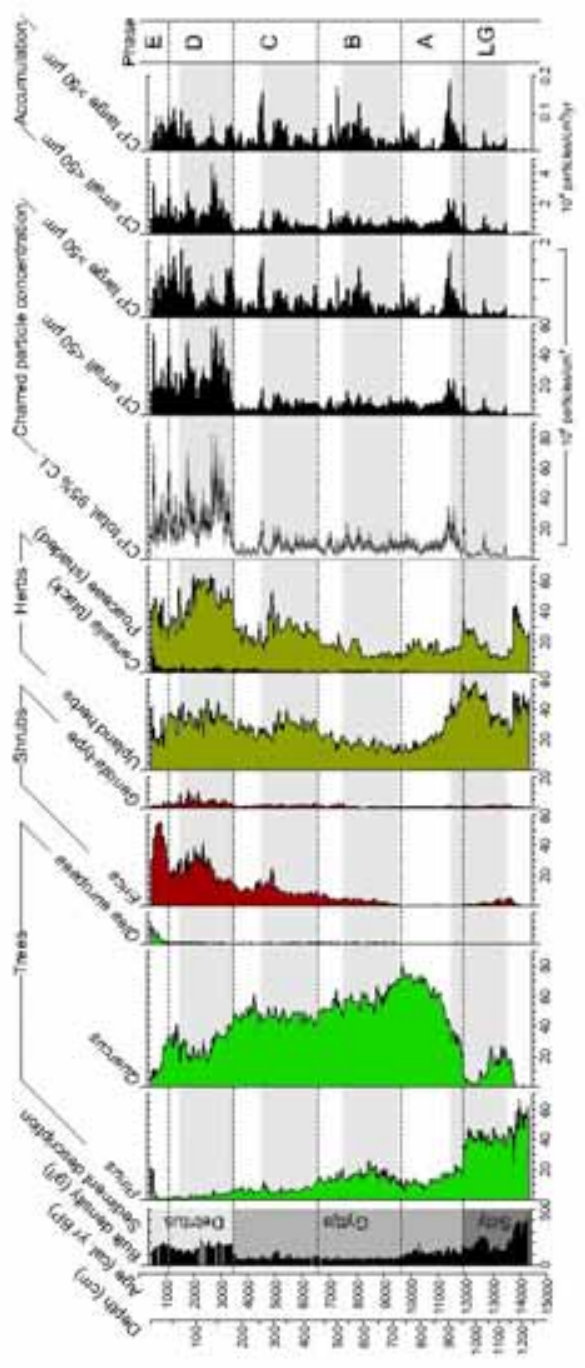

869

870 Figure 3. Stratigraphic diagram of proxies analysed in the Charco da Candieira sediment

871 record. From left to right: depths, modelled ages, sediment bulk density (g/l dry weight),

872 sediment description (details in der Knaap and van Leeuwen 1995, 1997), selected

873 pollen percentages, total charred particle concentrations with $95 \%$ confidence intervals

874 (estimated from Maher, 1972), concentrations of charred particles 5-50 and 50-250 $\mu \mathrm{m}$

875 in size, and accumulation rates of the same. Palaeovegetation phases (Section 2) shown

876 at right; grey horizontal bands are time-series analysis periods (Fig. 4). 


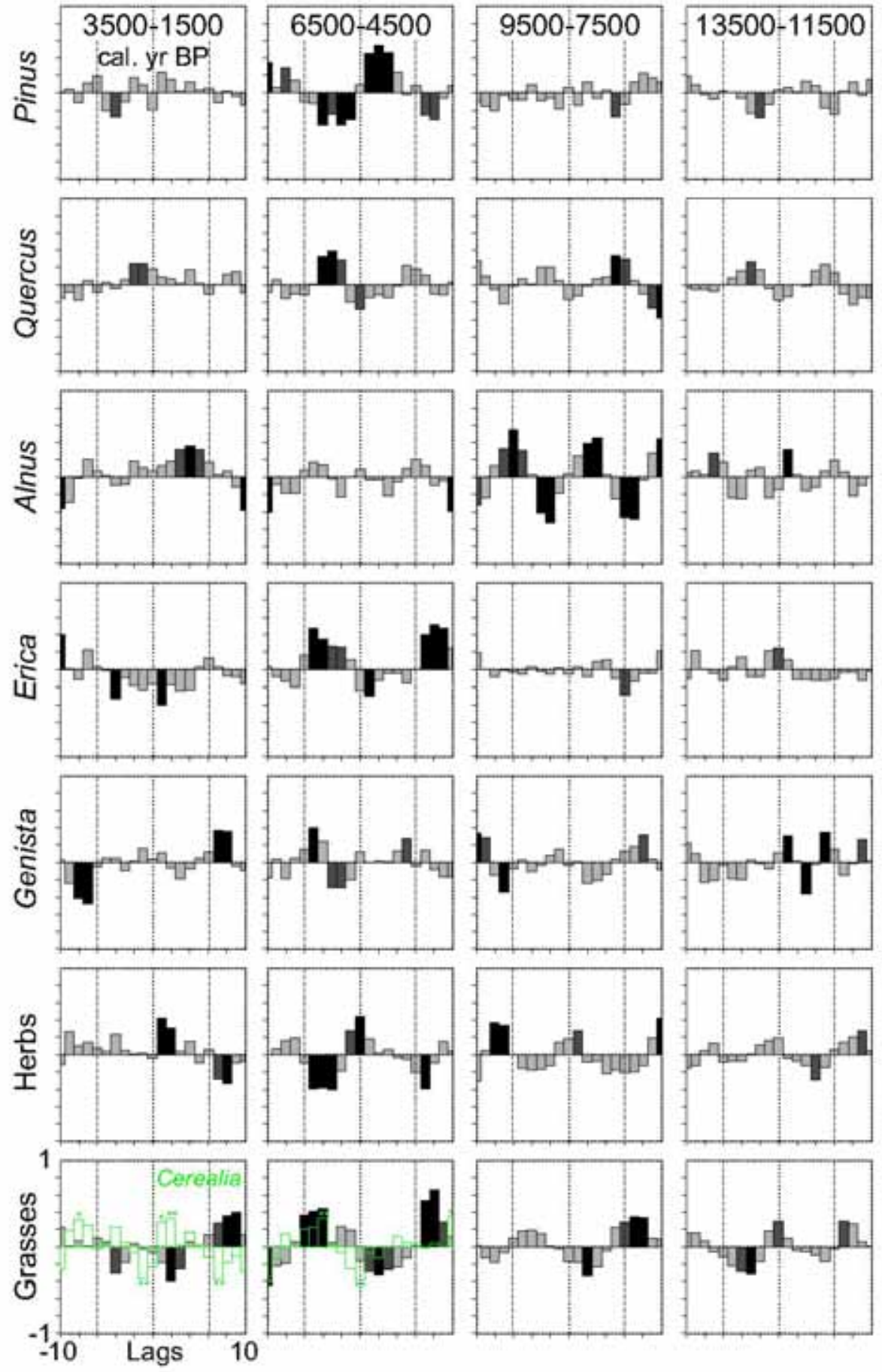

879 Figure 4. Cross-correlograms of interpolated and detrended pollen percentages (selected

880 taxa) and charred particle concentrations for four periods in the Charco da Candieira

881 record. The vertical axis represents correlation coefficients and the horizontal axis

882 represents lags (each equivalent to 48 years). Statistically significant correlations are 
883 indicated by black columns $(p<0.05)$ and dark-grey columns $(p<0.1)$. Cerealia pollen is

884 represented as hollow columns on the Poaceae graph $\left(* * p<0.05\right.$ and $\left.{ }^{*} p<0.1\right)$. When

885 reading these graphs, a positive correlation at zero lags (centre of each graph) indicates

886 a direct (immediate) correlation between charcoal and pollen abundance. A positive

887 correlation to the right indicates that a charcoal increase leads a pollen increase. A

888 positive correlation to the left indicates that the charcoal lags behind the pollen (see

889 Green, 1981, for full explanation). Dashed vertical lines at 6 lags denote the average

890 period between major charcoal peaks (approx. 300 years).

891
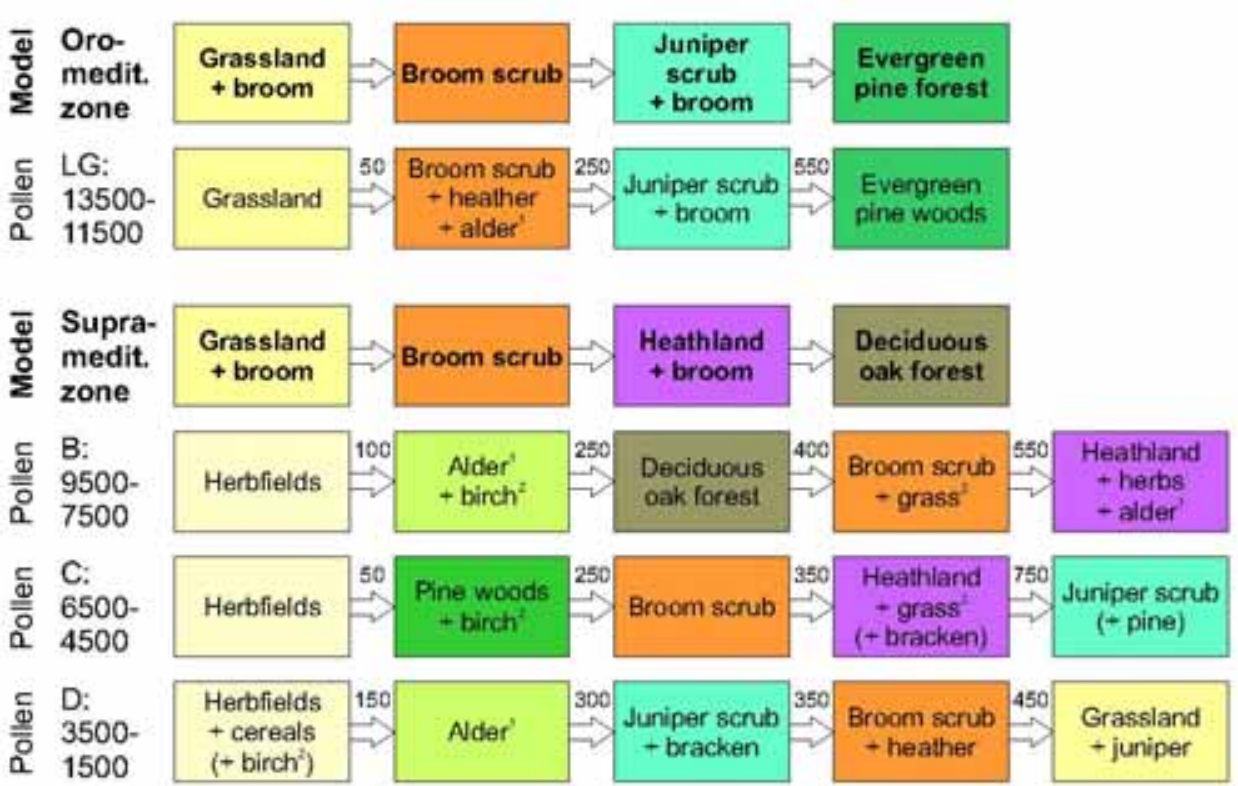

892 Figure 5. Comparison of a model of post-fire succession in the Serra da Estrela's oro-

893 mediterranean and supra-mediterranean vegetation (Jansen, 2011) with successional

894 trends deduced from time-series analysis of the Charco da Candieira pollen and charcoal

895 record (Section 5.3). Significant post-fire pollen correlations have been translated into

896 vegetation types to aid comparison. Numbers above the arrows indicate the approximate

897 number of years since fire required to reach each stage. Taxa marked 1 are possibly 
898 derived from long-distance pollen transport; taxa marked 2 may have occurred in the

899 local wetland vegetation; taxa in parentheses appear late in the successional stage in 900 which they are included.

901
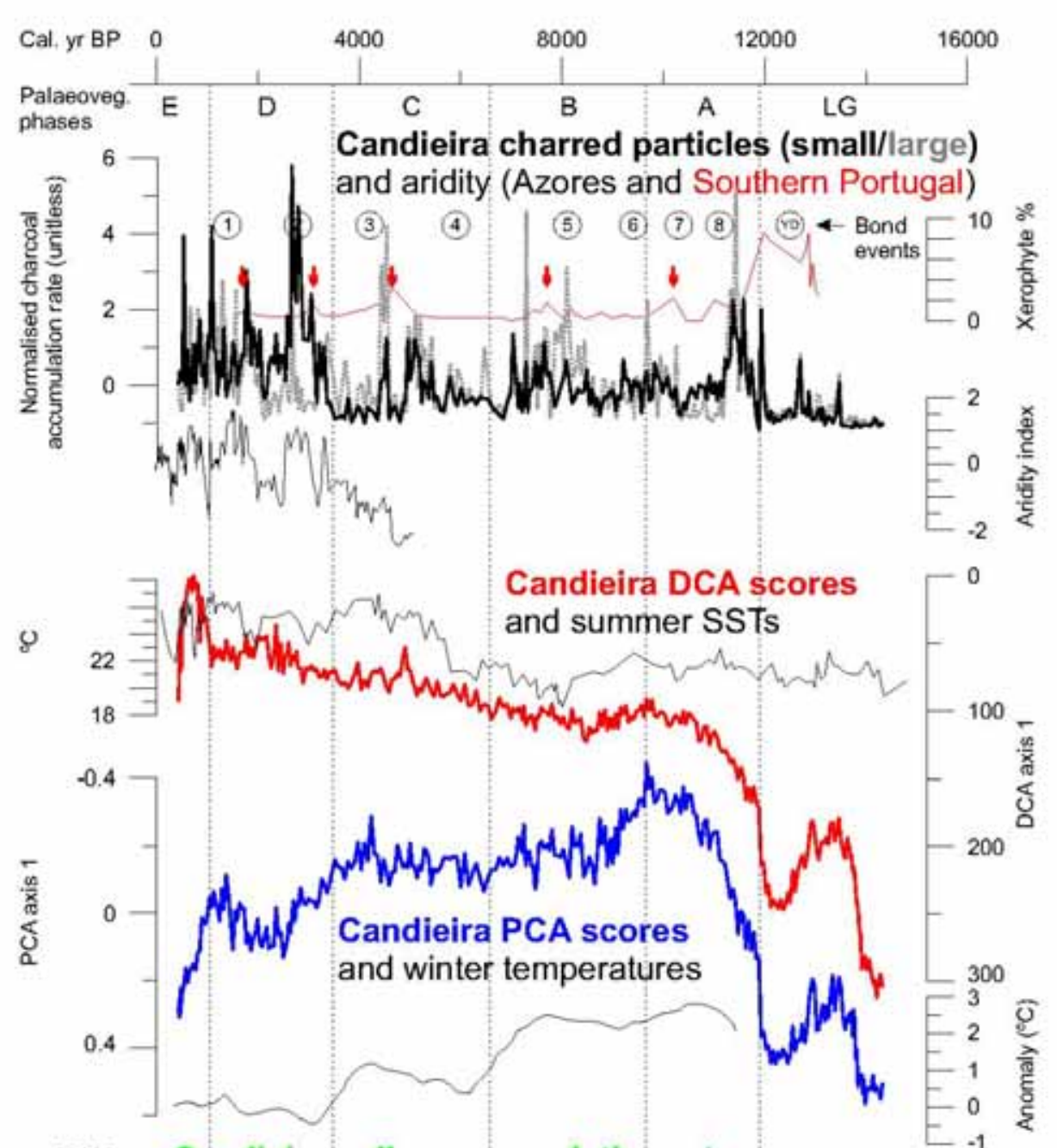

902

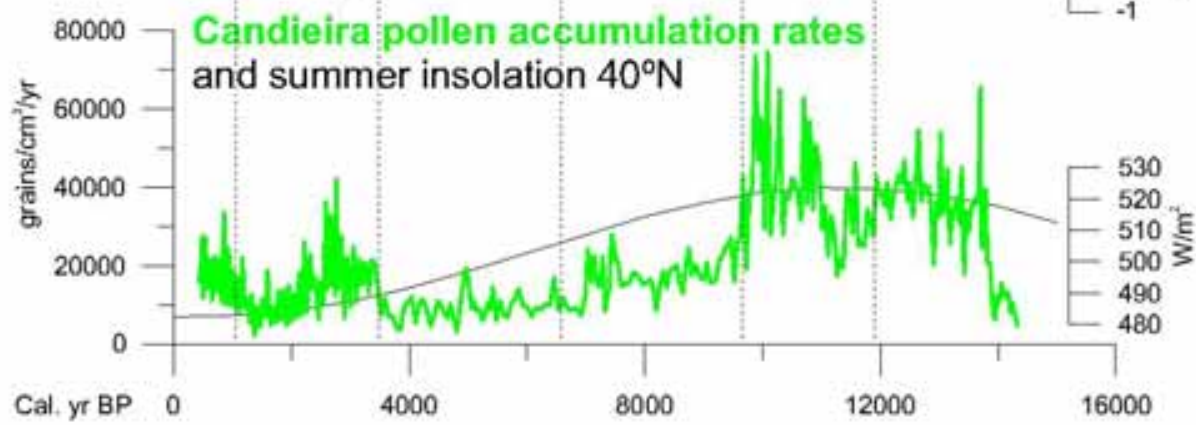

903 Figure 6. Ordination results (PCA and DCA), normalised charred-particle accumulation

904 rates and dryland-pollen accumulation rates from the Charco da Candieira record (thick 
905 lines) in relation to other palaeoclimatic records mentioned in the text (thin lines).

906 Charcoal data normalised to standard deviation (see Carcaillet et al., 2002). Azorean

907 aridity index redrawn from Björck et al. (2006); arid phases in Southern Portugal from

908 Fletcher et al. (2007); Bond events from Bond et al. (1997); summer sea surface

909 temperatures (SSTs) off West Africa from deMenocal et al. (2000); winter temperatures

910 in Morocco from Cheddadi et al. (1998); and summer insolation at $40^{\circ} \mathrm{N}$ from Berger

911 (1978). 